
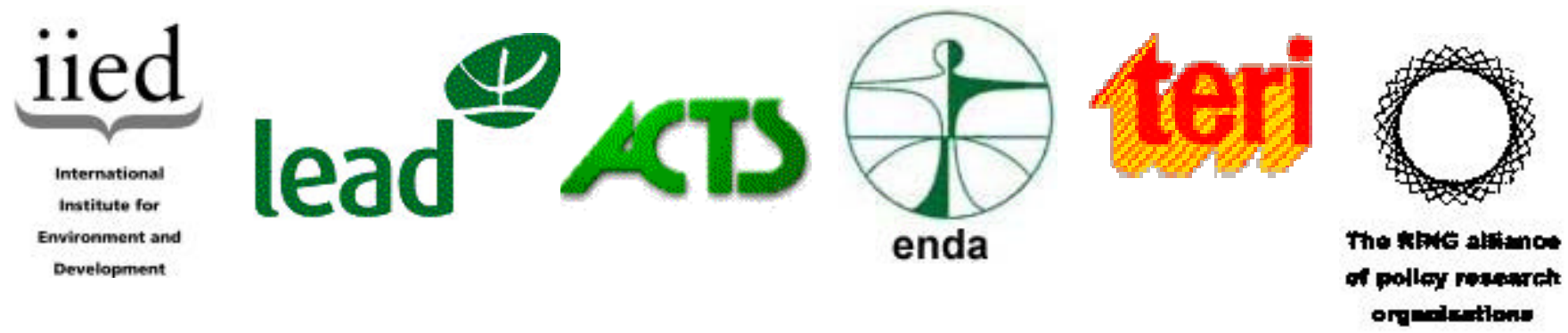

\title{
Climate Change and Development
}

\section{CONSUltation ON Key RESEARCHABLE ISSUES}

\section{SECTORAL ISSUES}

SECTION 2.5. HEALTH

HaNnaH ReID, LaUrel MurRay and Sari Kovats

Saleemul Huq and Hannah Reid

Climate Change Group

International Institute for Environment and Development

3 Endsleigh Street, London WC1H 0DD, UK

Tel: (+44 20) 73882117

Fax: (+44 20) 73882826

Email: saleemul.huq@iied.org hannah.reid@iied.org 


\section{Climate Change and Health}

The World Health Organization (WHO) has acknowledged that climate change may have major consequences for human health.

"We have evidence to state that climate change - by altering weather patterns and by disturbing life-supporting natural systems and processes - affects the health of human populations. There are many effects of these changes. And there is still discussion on the exact causality between human behaviour and climate change. But we know enough to take this very seriously and we have every reason to be concerned about adverse consequences for human health."

Dr Gro Harlem Brundtland, Director-General, World Health Organization. Speech at Geneva, World Meteorological Day, 23 March 1999

"Although risk may be low compared with current acute health crises, the attributable burden of such a widespread global phenomenon may be quite high"

Patz and Kovats (2002)

Climate change may affect human health through a range of pathways (see table below). Reviews of the range of impacts and mechanisms (and current scientific evidence) have been conducted by the WHO (McMichael et al. 2003) and the IPCC, which has a dedicated chapter on health (McMichael and Githeko 2001). Information and research on 'adaptation' responses as they relate to public health policy has been less well developed (WHO 2000; Ebi et al. in press). However, this should be considered in the context of the wealth of research and policy activity in relation to climate-sensitive diseases, particularly malaria, dengue, diarrhoal disease and undernutrition, that focuses on the development and implementation of cost-effective control measures. Currently, tuberculosis, HIV/AIDs and malaria dominate health and development policy on infectious diseases (Molyneux 2001).

Health adaptation to climate change should be part of integrated development policies designed to:

- manage ecosystems so that they continue to provide the goods and services on which health depends; 
- build on current policies to protect health, the environment and economic development against current climate variability and extremes (the 'adaptation baseline'); and

- make incremental changes to the adaptation baseline to reduce health hazards from direct and indirect climate change ('climate change adaptation').

The impact of climate change on a given population will depend on the prevalence of climate-sensitive diseases (e.g. malaria). Currently, the burden of these diseases is large. WHO has recently estimated that 150,000 deaths per year are currently attributable to climate change, and these deaths predominantly are in low-and middle-income countries (Ezzati et al. 2002). Although development and improvements in health care and other infrastructure will reduce some of this attributable burden, there is a clear need to develop the most appropriate strategies, policies and measures to improve adaptive capacity within the health sector.

\section{Summary of the range of climate sensitive diseases}

\begin{tabular}{|c|c|}
\hline Health outcome & Known effects of weather and climate variability \\
\hline Heat stress & $\begin{array}{l}\text { Deaths from cardiopulmonary disease increase with high } \\
\text { temperatures } \\
\text { - Heat-related illness and death increase during heat waves }\end{array}$ \\
\hline $\begin{array}{l}\text { Air pollution-related } \\
\text { mortality and } \\
\text { morbidity }\end{array}$ & $\begin{array}{l}\text { - Weather affects air pollutant concentrations } \\
\text { - Weather affects distribution, seasonality and production of } \\
\text { aeroallergens }\end{array}$ \\
\hline $\begin{array}{l}\text { Health impacts of } \\
\text { weather disasters }\end{array}$ & $\begin{array}{l}\text { - Floods, landslides and windstorms cause direct effects (deaths and } \\
\text { injuries) and indirect effects (infectious disease, psychological } \\
\text { morbidity) } \\
\text { - Droughts are associated with increased risk of disease, and } \\
\text { malnutrition }\end{array}$ \\
\hline $\begin{array}{l}\text { Mosquito-borne } \\
\text { diseases, tick borne } \\
\text { diseases } \\
\text { (e.g. malaria, dengue) }\end{array}$ & $\begin{array}{l}\text { - Higher temperatures shorten the pathogen development time in the } \\
\text { vectors and increase potential transmission to humans } \\
\text { Each vector species has specific climate conditions (temperature, } \\
\text { humidity) necessary to be sufficiently abundant to maintain } \\
\text { transmission }\end{array}$ \\
\hline Under nutrition & $\begin{array}{l}\text { - Climate change may decrease food supplies (crop yields, fish stocks) } \\
\text { or access to food supplies }\end{array}$ \\
\hline $\begin{array}{l}\text { Water / food-borne } \\
\text { diseases }\end{array}$ & $\begin{array}{l}\text { - Survival of disease organisms is related to temperature } \\
\text { - Water-borne diseases are most likely to occur in communities with } \\
\text { poor water supply and sanitation } \\
\text { - Increases in drought conditions may affect water availability } \\
\text { Extreme rainfall can affect transport of disease organisms into water } \\
\text { supply }\end{array}$ \\
\hline
\end{tabular}

Source: Kovats et al. in press

An important impact of health will be via extreme events (floods, storms and heat waves). The heat waves in 2003 in Europe overshadowed the occurrence of serious 
heat waves in India and elsewhere. Floods are the most frequent disaster events and are associated with mortality, and an unknown burden of morbidity, including effects on mental health (Few et al. 2004; Ahern et al. 2005). The effects result from inadequate water and sanitation infrastructure, as well as disturbances to more complex ecological processes and include the spread of vector-borne diseases such as malaria.

Changes in animal health will affect human welfare and health (Jonsson and Reid 2000). For example, important livestock diseases will have knock on effects for human health. And diseases such as Rift Valley Fever affect both cattle and humans. It has been suggested that climate change may affect important vector borne diseases. "Medical, agronomic and livestock scientists have traditionally taken different approaches to the development of first-generation assessments of possible global change impacts within their disciplines. However, holistic, integrated assessments are necessary to provide advice in a form that is suitable for use by policy makers" (Sutherst et al. 1998).

Studies that focus on a single disease or health outcome provide an incomplete picture of the impacts of climate change on human health. Robust health impact assessments for climate change are needed at the national or regional level. WHO has recently launched guidance for climate change health impact assessment (WHO 2003), and has organized several workshops in small island states to support capacity building for climate and health.

Some industrialized countries have undertaken health focused national assessments of impacts and adaptation, e.g. Australia (McMichael et al. 2002), the UK (by the Department of Health in 2002), Portugal (Calheiros and Casemiro 2002) and the US (Patz et al. 2000). These assessments have quantified or qualitatively assessed the effects of climate change on heat-related and air pollution related mortality and morbidity, and on flood and windstorms. Although there are concerns about the emergence of new vector-borne diseases in these countries, the effects are likely to be small and localized. However, there are serious concerns about dengue becoming established in Australia and New Zealand (de Wet et al. 2001).

Poor countries and low-income populations are most vulnerable to the health impacts of climate change (Bloom 2004). "Any region or population with concurrent environmental or socioeconomic stresses will be at risk" (Patz and Kovats 2002). 
Molyneux (2003) states, "studies suggest that infectious diseases will contribute a proportionately smaller burden of disease over the next two decades as noncommunicable diseases emerge as public health problems. However, infectious diseases contribute proportionately more in the poorest quintile of the population."

Epidemiological studies of population level impacts of current climate variability is an important first step in describing current and future vulnerability to climate change. Studies of the impact of El Niño Southern Oscillation (ENSO) events as a determinant of interannual climate variability have provided strong evidence for certain local effects of inter-annual climate variability on malaria in Venezuela (Bouma 2003) and coastal cholera in Bangladesh (Pascual et al. 2002), as assessed in a systematic review by Kovats et al. 2003a.

Malaria is probably the most important climate sensitive infectious disease, and this has been reflected in the research activity. There have been several studies, using a range of methods, to quantify the impact of climate change on malaria in terms of the global or regional population at risk (van Lieshout et al. 2004; Tanser et al. 2003; Martens et al. 1999, Rogers and Randolph 2000). Estimates based on the validated MARA model for Africa, indicate that the densely populated East African highlands are most at risk of climate change related increases in malaria transmission. Since the late 1980s, epidemics of malaria in the African highlands have become more widespread and occur more frequently, probably due to increased drug resistance rather than observed climate change. Studies of malaria epidemics in particular localities have suggested strongly that at the local level a number of non-climatic factors are significant in explaining increases in malaria transmission, such as changes in water management and land use. There is little reliable malaria information that goes back a sufficient number of years to examine historical links between climate and malaria (Rogers and Randolph 2000).

Vector-borne disease control programmes have been initiated in several poor countries and regions. These include mosquito control units, tsetse control units, and regional multi-country/multi-donor control programmes such as the Onchocerciasis Control Programme and Chagas Disease Control Programme of the Southern Cone, South America. 
Droughts unfold over longer periods than floods, and their impacts tend to be on livelihoods and human health rather than infrastructure. Infectious diseases are a major cause of illness and death during famines. Malnutrition increases the risk of dying from an infectious disease, particularly diarrhoea. Outcomes associated with drought are crop failure, large-scale loss of livestock and famine. These are in turn associated with factors such as migration, in particular of the rural poor to cities, which can lead to increased urban poverty and associated problems including increased transmission of HIV/AIDS. The recent food crisis in Southern Africa, which was in part due to drought, was made much worse because HIV/AIDS has created a new class of vulnerable households, increased the population at risk and changed the course of recovery (de Waal and Whiteside 2003). It is therefore important the health interventions for drought are not confined to food aid (Griekspoor et al. 2004).

Climate change related health problems in urban areas are a growing concern. Rapidly expanding urban populations are a feature of many low-income countries. Populations in informal settlements have poor housing and limited access to improved water and sanitation. Water supplies in poor cities can be sensitive to relatively small decreases in supply. The implications of climate change on the operation of drainage systems and adverse changes caused by changes in flood frequencies have not been addressed in the literature. Climate change may also increase heat stress and exacerbate urban outdoor air pollution. Mortality due to heat waves in India was reported to be mainly among the poor, elderly and labourers such as agricultural workers and rickshaw pullers.

\section{Using climate information to reduce the burden of disease}

The Disability Adjusted Life Year (DALY) accounts for years of life lost to premature death and/or morbidity, and can thus be used to rank risks and to motivate and target risk management efforts (Nelson 2003). Mapping 'hotspots' of risk may prove useful for prioritizing and focusing resources for health planning (Patz and Kovats 2002). These tools can help improve methods for health impact assessment, but new approaches to surveillance (such as those that have been supported through the DFID Malaria Knowledge Programmes) are needed in order to allow monitoring of vector-borne diseases in sensitive areas.

Epidemic preparedness for malaria and other diseases may benefit from recently developed tools that predict the seasonality and risks of epidemics using satellite or 
ground-based meteorological data (WHO 2004). New approaches to mapping the distribution of disease vectors over large areas will facilitate species-specific vector control activities for malaria (Tanser and le Sueur 2002) and other vector-borne diseases, including guinea worm, onchocerciases, lymphatic filariasis and African typanosomiasis (sleeping disease) (Molyneux 2001).

\section{Research Needs on the Health Impacts of Floods}

Few et al. (2004) "make the following recommendations for the design of epidemiological studies that investigate the health impacts of floods: control groups for comparison with non-flooded populations; use of longitudinal data, or routine data in order to gain information on pre-flood levels of disease; use of objective measures of disease outcome; and improved use of routine surveillance information. Priorities for future research include: the impacts of flooding on long-term mental health in both industrialised and developing countries; the impact of flooding and heavy rainfall on diarrhoeal disease, and the main routes of transmission; indirect mortality attributable to flooding (in addition to immediate deaths from drowning); and impacts on health from the disruption of health services and other life supporting systems."

\section{Challenges for Research}

Although health surveillance data in low-income countries is limited, there have been several recent initiatives to improve the situation, and implement long term sustainable monitoring activities. It is important that surveillance is supported and maintained in order to detect the early effects of climate change (Kovats et al. 2001).

Improved research methods and skills are also needed. Nelson (2003) states that "improved methods are needed to predict and quantify health impacts, so that appropriate risk management strategies can be focused on vulnerable areas". Technical skills in vector biology and control, at all levels, have been declining in less developed countries (Molyneux 2001).

Poverty, lack of funding and limited capacity to introduce required health precautions are also major challenges. There is much current work focussed on the scaling up of interventions, such as the use of social marketing to distribute insecticide treated bednets to reduce malaria. 
The use of clean energy in poor communities offers opportunities to both reduce greenhouse gas emissions and reduce indoor air pollution and subsequent health impacts. There is much scope for research on this issue. 


\begin{abstract}
Climatic Hazards, Health and Adaptation
Dr Roger Few,

Senior Research Fellow, School of Development Studies, University of East Anglia

Climatic hazards such as flood, drought, thermal extremes and storm events bring widespread impacts on health in developing countries. The prospect of changes in the extent, magnitude and dstribution of climatic hazards as a result of climate change therefore compounds an already severe public health problem that tends to impact most heavily on low-income and marginalised groups (McMichael et al. 2003). The health risks tend to be magnified in contexts where the state's capacity to provide protection measures against disease is relatively weak, where environmental health conditions are often poor, and where poverty and vulnerability to hazards may reinforce one another in a cyclical relationship. Yet, despite the often grave concerns for public health expressed in the aftermath of hazard events - highlighted again after the 2004 tsunami disaster - insufficient research attention is directed to the means by which vulnerable populations and the institutions charged with health protection respond to those risks.
\end{abstract}

Climatic hazards impact on health both in a direct sense via injury and exposure, and in an indirect sense via changes in exposure to vectors and pathogens, psychosocial disturbance, impacts on food supply and impacts on health care services themselves. Often, these indirect health consequences arise via complex pathways associated with environmental disturbance and human behavioural change (Wisner \& Adams 2002). The outcomes of these health risks are mediated by a range of coping responses, within households, communities, health systems and associated sectors such as environmental health and emergency services. In the context of additional threats posed by climate change, it is vital to improve our understanding of health-related response to hazards and, in particular, to analyse the challenges, constraints and opportunities for enhancing resilience and preparedness at all levels (Few et al. 2004). Greater preparedness within health systems, for example, can play a crucial role in health risk reduction in two senses: by reducing public vulnerability to short- and long-term health impacts of hazards; and by reducing vulnerability of health systems themselves to damage and disruption caused by severe climatic events.

In addition to further research on the epidemiology of hazard risk and the health 
implications of climate change, there is a need for cross-disciplinary work to examine the processes that shape differential vulnerability and response in developing countries, and thereby to assess the prospects for adaptation to health risks from future hazards:

\section{Understanding present-day vulnerability and response}

$>$ How do people and institutions in low-income societies perceive and respond to current health impacts of climatic hazards?

$>$ How do responses to different forms of hazard vary?

$>$ What role does difference in policy environment, health system organisation and wider structural context play in defining individual/institutional response capacities?

$>$ What role does differential entitlement to resources and livelihood assets play in shaping individual response capacities and decision-making?

\section{Assessing adaptation options}

$>$ What are the most effective and feasible modes of response to climatic hazard health risks identified in low-income countries?

$>$ What are the implications for response effectiveness of future levels of risk related to climate change?

$>$ Can positive lessons be replicated through communication and intervention to enhance adaptation to future climate risks?

$>$ What changes at structural and agency levels can most enhance capacity to adapt?

This work should seek to identify key loci for adaptive response within the social and environmental processes that generate health vulnerability - opportunities through which resilience to health risks can be most effectively enhanced. Such efforts will in most cases bring contemporary benefits for present hazard-prone populations, as well as promote anticipatory adaptation to the potential impacts of climate change.

\section{References}

Few, R., Ahern, M., Matthies, F. and Kovats, S., 2004. Floods, health and climate change: a strategic review. Tyndall Centre Working Paper 63.

> McMichael, A., Campbell-Lendrum, D., Corvalan, C., Ebi, K., Githeko, A., Scheraga, J. and Woodward, A. (eds), 2003. Climate change and human 
health: risks and responses. World Health Organization, Geneva.

$>$ Wisner, B. and Adams, J. (eds), 2002. Environmental health in emergencies and disasters. World Health Organization, Geneva. 


\section{Health, Development and Climate Change \\ Sari Kovats \\ Lecturer, Centre on Global Change and Health, London School of Hygiene and Tropical Medicine}

There are many uncertainties in assessing the potential health impacts, as climate change scenarios are highly uncertain at the spatial and temporal resolution most appropriate for health impact assessment. Research activities have shifted towards identifying those populations most vulnerable to the health impacts of climate change, and the development of effective adaptation strategies.

Health impact assessment (which includes both environmental and social assessment) should be a dominant feature of policy development. Public health and disease prevention measures are often not given the attention they deserve. Health researchers generally accept that many diseases are climate-sensitive, and therefore potentially affected by climate change. The frameworks that are used to assess climate change risks to health, and the way that the results are presented, are therefore critical for a potentially difficult dialogue between health and climate change researchers and policy-makers, stakeholders and the general public (Kovats et al. 2005).

'Adaptation' measures can be used effectively to greatly reduce many of the potential health impacts of climate change. Environmental interventions are nearly always cost-effective, and have widespread benefits beyond the immediate health effects (e.g. improved access to water in the home frees up the time of women for education). Many diseases and public health problems that may otherwise be exacerbated by climate change could be substantially prevented with adequate financial and human public health resources. These resources would encompass public health training programs, research to develop and implement more effective surveillance and emergency response systems, and sustainable prevention and control programs (DFID 2000). Low-income countries already have spending well below that required to control infectious disease.

\section{Key researchable issues}

- Capacity building through national climate change impact and adaptation assessment, with research to improve methods for quantifying the burden of 
disease due to climate variability and climate change.

- Research on the effectiveness (and cost-effectiveness) of adaptation strategies (including both those delivered through the health sector and those through other sectors), particularly the use of seasonal forecasts to provide early warning of epidemics or disasters.

- Potential impacts of climate change on the achievement of the Millennium Development Goals, especially nutrition and child mortality.

- The implications for public health of climate change - via changes in disaster frequency and intensity, and the development of appropriate response strategies.

\section{Climate Change and Health - Key References}

Adger, W. N. et al. (2001) Climate Change 2001: Impacts, Adaptation, and Vulnerability. Chapter 11. Contribution of Working Group II to the Third Assessment Report to the IPCC. Cambridge, Cambridge University Press.

Ahern, M. J., R. S. Kovats, P. Wilkinson, R. Few and F. Matthies (2005) Global health impacts of floods: a systematic review of epidemiological evidence. Epidemiological Reviews. In press.

Allali, A. et al. (2001) Climate Change 2001: Impacts, Adaptation, and Vulnerability. Chapter 10. Contribution of Working Group II to the Third Assessment Report to the IPCC. Cambridge, Cambridge UP.

Balbus, J. M. and M. L. Wilson (2000) Human Health and Global Climate Change: A Review of Potential Impacts in the United States. Pew Center on Global Climate Change. http://www.pewclimate.org/global-warming-indepth/all reports/human health/index.cfm

Bloom, G. (2004) Health in a Changing World. IDS Bulletin Climate Change and Development 35(3): 38-41.

Bouma, M. J. (2003) Climate change and tropical disease: Methodological problems and amendments to demonstrate effects of temperature on the epidemiology of malaria. A new perspective on the highland epidemics in Madagascar, 1972-89. Transactions of the Royal Society of Tropical Medicine and Hygiene 97: 133-139.

Caeseele, R. V. (2002) Climate Change and Health. Climate Change Connection. www.climatechangeconnection.org/pages/health.html

Casimiro, E. and J. M. Calheiros (2002) Human Health. In F. D. Santos, K. Forbes and R. Moita (eds) Climate Change in Portugal: Scenarios, Impacts, and Adaptation Measures. SIAM project: Lisbon, Gradiva, p. 241-300. 
Checkley, W., L. D. Epstein, R. H. Gilman, D. Figueroa, R. Cama, J. A. Patz and R. E. Black (2000) Effects of El Nino and ambient temperature on hospital admissions for diarrhoeal diseases in Peruvian children: Lancet 355.

de Waal, A. and A. Whiteside (2003) New varient famine: AIDS and food crisis in southern Africa. Lancet 362: 1234-37.

de Wet, N., W. Ye, S. Hales, R. A. Warrick, A. Woodward and P. Weinstein (2001) Use of a computer model to identify potential hotspots for dengue fever in New Zealand. New Zealand Medical Journal 11(1140): 420-422.

Deubel, V. and R. Rodhain (1999) Climate variations and dengue fever: direct and indirect impacts. Médecine et Maladies Infectieuses 29(5): 289-295.

DFID (2000) Better health for poor people. Strategies for achieving the international development goals. Department for International Development, London.

Ebi, K., J. Smith and I. Burton (eds) (in press) Integration of Public Health with Adaptation to Climate Change: Lessons learned and New Directions. Taylor and Francis Group, Lisse, The Netherlands.

El-Zeinand, A. and M. Tewtel-Salem (2005) On the association between high temperature and mortality in warm climates. Science of The Total Environment. In Press.

Epstein, P. R. (2001) Climate change and emerging infectious diseases. Microbes and Infection 3(9): 747-754.

Ezzati, M., A. D. Lopez, A. Rodgers, S. Vander Hoorn, C. J. L. Murray (2002) Comparative Risk Assessment Collaborating Group. Selected major risk factors and global and regional burden of disease. Lancet 360: 1347-1360.

Fagan, B. (1999) Floods, Famines and Emperors: El Nino and the Fate of Civilisations. Basic Books, New York.

Few, R. (2003) Flooding, vulnerability and coping strategies: local responses to a global threat. Progress in Development Studies 3(1): 43-58.

Few, R., M. Ahern, F. Matthies and S. Kovats (2004) Floods, Health and climate change: a strategic review. Tyndall Centre for climate change research. Working paper 63.

Githeko, A. K., S. W. Lindsay, U. E. Confalonieri and J. A. Patz (2000) Climate change and vector borne diseases: a regional analysis: Bulletin of the World Health Organization 78(9): 1136-1147.

Griekspoor, A., P. Spiegal, W. Aldis and P. Harvey (2004) The health sector gap in the Southern Africa crisis in 2002/2003. Disasters 28(4): 388-404.

Hales, S., N. de Wet, J. Maindonald and A. Woodward (2002) Potential effect of population and climate changes on global distribution of dengue fever: an empirical model. Lancet 360: 830-834.

Hitz, S. and J. Smith (2004) Estimating global impacts from climate change. Global Environmental Change Part A, 14(3): 201-218. 
Hopp, M. and J. Foley (2001) Global-scale relationships between climate and the dengue fever vector, Aedes Aegypti. Climatic Change 48: 441-463.

IRI (2005) Sustainable development in Africa: Is the climate right? IRI Position Paper. IRI Technical Report IRFTR /05/01. New York, International Research Institute for Seasonal to Interannual Prediction.

Jonsson, N. N. and S. W. J. Reid (2000) Global Climate Change and Vector Borne Diseases. The Veterinary Journal 160(2): 87-89.

Kalkstein, L. S. and J. S. Greene (1997) An evaluation of climate/mortality relationships in large US cities and the possible impacts of climate change. Envirol Hith Pers 105(1): 84-93.

Kalkstein, L. S. (1990) Climate change and public health: What do we know and where are we going? Environmental Impact Assessment Review 10(4): 383392.

Kilbourne, E. (1997) Heatwaves. In E. Noji (ed.) The public health consequences of disasters. Oxford University Press, Oxford and New York. Pp. 51-61.

Kiska, D. L. (2000) Global Climate Change: An Infectious Disease Perspective Clinical Microbiology Newsletter 22(11): 81-86.

Kosek, M., C. Bern and R. L. Guerrent (2003) The global burden of diarrhoeal disease, as estimated from studies published between 1992 and 2000. Bulletin of the World Health Organization 81(3) 197-204.

Kovats, R. S., B. Menne, A. J. McMichael, R. Bertollini and C. Corvalan (2000) Climate Change and Human Health: Impact and Adaptation. World Health Organization, Geneva.

Kovats, R. S., D. Campbell-Lendrum, A. J. McMichael, A. Woodward, J. Cox (2001) Early effects of climate change: do they include changes in vector borne diseases? Philosophical Transactions of the Royal Society B 356: 1057-1068.

Kovats S., M. J. Bouma, S. Hajat, E. Worrell and A. Haines (2003a). El Nino and health. Lancet 361: 1481-1489.

Kovats, R. S., B. Menne, M. J. Ahern and J. A. Patz (2003b) National assessments of health impacts of climate change: a review. In A. J. McMichael, D. H. Campbell-Lendrum, C. F. Corvalán, K. L. Ebi, A. K. Githenko, J. D. Scheraga and A. Woodward (eds) Climate Change and Human Health: Risks and Responses. WHO, Geneva. Pp. 181-200.

Kovats, R. S., D. Campbell-Lendrum, F. Matthies (2005 in press) Climate change and human health: Estimating avoidable deaths. Risk Analysis (special issue) in press.

Loevinsohn, M. E. (1994) Climatic warming and increased malaria incidence in Rwanda. The Lancet 343(8899): 714-718.

Malilay, J. (1997) Floods. In E. Noji (ed.) The public health consequences of disasters. Oxford University Press, New York. 
Martens, P., R. S. Kovats, S. Nijhof, P. de Vries, M. T. J. Livermore, D. J. Bradley, J. Cox and A. J. McMichael (1999) Climate change and future populations at risk of malaria. Global Environmental Change 9(1): S89-S107.

Martens, W. J. M. and A. J. McMichael (eds) (2002) Environmental Change, Climate, and Health: Issues and Research Methods. Cambridge University Press, Cambridge.

McCarthy, J. J., O. Canziani, N. A. Leary, D. J. Kokken and K. S. White (2001) Climate change 2001: impacts, adaptation, and vulnerability. UN Intergovernmental Panel for Climate Change. Third assessment report. Cambridge University Press, New York.

McMichael, A. J. and R. S. Kovats (2000) Climate change and climate variability: adaptations to reduce adverse health impacts. Environmental Monitoring and Assessment 61: 49-64.

McMichael, A. J. (1995) Global climate change and health. The Lancet 346 (8978): 835.

McMichael, A. J., U. E. Confalonieri, A. K. Githeko, P. Martens, R. S. Kovats, J. A. Patz, A. Woodward, A. Haines and A. Sasaki (2001) Human Health. In B. Metz, O. R. Davidson, W. J. Martens, S. N. M. van Rooijen and L. V. W. McGrory (eds) Methodological and Technological Issues in Technology Transfer. Cambridge University Press, Cambridge. Pp. 331-347.

McMichael, A. J., R. Woodruff, P. Whetton, K. Hennessy, S. Hales, A. Woodward and T. Kjellstrom (2002) Human health and climate change in Oceania: A Risk Assessment. Commonwealth of Australia. www.health.gov.au/pubhlth/strateg/envhlth/climate/

McMichael, A. J. et al. (2004) Climate Change. In Comparative qualification of health risks. Vol. 1. WHO, Geneva.

McMichael, A. J., D. H. Campbell-Lendrum, C. F. Corvalán, K. L. Ebi, A. K. Githenko, J. D. Scheraga and A. Woodward (eds) (2003b) Climate Change and Human Health: Risks and Responses. WHO, Geneva. http://www.who.int/globalchange/climate/summary/en/

McMichael, A. J. and A. Githeko (2001) Climate Change 2001: Impacts, Adaptation, and Vulnerability. Chapter 9. Contribution of Working Group II to the Third Assessment Report to the IPCC. Cambridge, Cambridge University Press.

Mitra, A., S. bhattacharya, R. C. Dhiman, K. K. Kumar, and C. Sharma (2004) Malaria in India and its future projections due to climate change.

Molyneux, D. H. (2001) Vector-borne infections in the tropics and health policy issues in the twenty-first century. Transactions of the Royal Society of Tropical Medicine and Hygiene 95(3): 233-238.

Molyneux, D. H. (2003) Climate change and tropical disease: Common themes in changing vector-borne disease scenarios. Transactions of the Royal Society of Tropical Medicine and Hygiene 97(2): 129-132. 
National Research Council (2001) Under the weather: climate, ecosystems, and infectious disease. National Academy Press, Washington, DC.

Nugent, O. (2004) Primer on Climate Change and Human Health. Pollution Probe www.pollutionprobe.org/Publications/Primers.htm

Nelson, D. I. (2003) Health impact assessment of climate change in Bangladesh. Environmental Impact Assessment Review 23(3): 323-341.

Noji, E. N. (1997) The public health consequences of disasters. Oxford University Press, New York.

Ogunseitan, O. A. (203) Framing environmental change in Africa: cross-scale institutional constraints on progressing from rhetoric to action against vulnerability. Global Environmental Change 13(2): 101-111.

Pascual, M., M. J. Bouma and A. P. Dobson (2002) Cholera and climate: revisiting the quantitative evidence: Microbes and Infection 4: 237-246.

Patz, J. A. M. A. McGeehin, S. M. Bernard, K. L. Ebi, P. R. Epstein PR, A. Grambsch, D. J. Gubler. P. Reiter, I. Romieu, J. B. Rose (2000) The potential health impacts of climate variability and change for the United States: executive summary of the report of the health sector of the U.S. National Assessment. Environmental Health Perspectives 108(4): 367-376.

Patz J, and S. Lindsay (1999) New challenges, new tools: the impact of climate change on infectious diseases commentary. Curr Opin Microbiol 2: 445-451.

Patz, J. A. and W. K. Reisen (2001) Immunology, climate change and vector-borne diseases. Trends in Immunology 22(4): 171-172.

Patz, J. A. (2001) Public Health Risk Assessment Linked to Climatic and Ecological Change. Human and Ecological Risk Assessment 7(5): 1317-1327.

Patz, J. A. and R. S. Kovats (2002) Hot spots in climate change and human health. British Medical Journal 325: 1094-1098.

Patz, J. A. and R. S. Kovats (2005) Hotspots in climate change and human health. British Medical Journal bmj.bmjjournals.com/cgi/content/full/325/7372/1094

Rogers, D. J. and S. E. Randolph (2000) The global spread of malaria in a future, warmer world. Science 289: 1763-1765.

Ruttan, V. W., D. E. Bell and W. C. Clark (19994) Climate change and food security: Agriculture, health and environmental research. Global Environmental Change 4(1): 63-77.

Singh, R. B. K., S. Hales, N. de Wet, R. Raj, M. Hearnden and P. Weinstein (2001) The influence of climate variation and change on diarrhoeal disease in the pacific islands: Environmental Health Perspectives 109: 155-159.

Smith, K. R. (2003) Wealth, poverty and climate change: Medical Journal of Australia 179: 571-572. 
Sondorp, E. and P. Patel (2003) Climate change, conflict and health. Transactions of the Royal Society of Tropical Medicine and Hygiene 97(2): 139-140.

Speelman, E. C., W. Checkley, R. H. Gilman, J. A. Patz, M. Calderon and S. Manga (2000) Cholera incidence and El Nino related higher ambient temperature. JAMA 283(23): 3072-3074.

Sutherst, R. W., J. S. I. Ingram and H. Scherm (1998) Global Change and Vectorborne Diseases. Parasitology Today 14(8): 297-299.

Sutherst, R. W. (2001) The vulnerability of animal and human health to parasites under global change. International Journal for Parasitology 31(9): 933-948.

Tanser, F. C. and D. le Sueur (2002) The application of geographical information systems to important public health problems in Africa. International Journal of Health Geographics 1: 4. Published online 2002 December 9.

Tanser, F. C., B. Sharp and D. le Sueur (2003) Potential effect of climate change on malaria transmission in Africa. The Lancet 362(9398): 1792-1798.

Thomas, C. J., G. Davies and C. E. Dunn (2004) Mixed picture for changes in stable malaria distribution with future climate in Africa. Trends in parasitology 20(5): 216-220.

US Global Change Research Program (2001) The Potential Consequences and Human Health Sector Contribution to the National Assessment on the Potential Consequences of Climate Variability and Change for the United States.

van Lieshout, M., R. S. Kovats, M. T. J. Livermore and P. Martens (2004) Climate change and malaria: analysis of the SRES climate and socio-economic scenarios. Global Environmental Change 14(1): 87-99.

Walker, H. A. (2001) Understanding and Managing the Risks to Health and Environment from Global Atmospheric Change: A Synthesis. Human and Ecological Risk Assessment 7(5): 1195-1209.

Woodward, A. J., S. Hales, N. Litidamu, D. Phillips and J. Martin (2000) Protecting human health in a changing world: the role of social and economic development. World Health Organisation Bulletin 78: 1148-1155.

WHO (1990) Potential Health Effects of Climatic Change. WHO Task Group, Geneva. http://www.ciesin.org/docs/001-007/001-007.html

WHO Task Force on Climate and Health (1999) El Niño and health. WHO, Geneva.

WHO (2000) Climate change and human health: impact and adaptation. Geneva, WHO and Rome, WHO-European Centre for Environment and Health, 2000. [WHO/SDE/OEH/00.4]

WHO (2001) Malaria Early Warning Systems, Concepts, Indicators and Partners: A framework for field research in Africa. Roll Back Malaria/Technical Support Network for Prevention and Control of Malaria. WHO, Geneva. 
WHO (2002) World Health Report 2002: Reducing risks, promoting healthy life. WHO, Geneva.

WHO (2003) Methods of Assessing Human Health Vulnerability and Public Health Adaptation to Climate Change. Health and Global Environmental Change Series No. 1. www.who.dk/document/E81923.pdf

WHO (2004) Using climate to predict disease outbreaks. WHO, Geneva.

Woodward, A., S. Hales, N. Litidamu, D. Phillips, J. Martin (2000) Protecting human health in a changing world: the role of social and economic development. Bull World Health Organ 78: 1148-1155.

Woodward, A., S. Hales and P. Weinstein (1998) Climate change and human health in the Asia Pacific region: who will be the most vulnerable? Climate Research 11: 31-38.

Woodward, A. and J. S. Scheraga (2003) Looking to the future: challenges for scientists studying climate change and health. In A. J. McMichael, D. H. Campbell-Lendrum, C. F. Corvalán, K. L. Ebi, A. K. Githenko, J. D. Scheraga and A. Woodward (eds) (2003b) Climate Change and Human Health: Risks and Responses. WHO, Geneva, Pp. 61-78.

World Bank (2004) Poverty and Climate Change: Reducing the Vulnerability of the Poor through Adaptation. Joint publication: African Development Bank, Asian Development Bank, DFID, Directorate General for International Cooperation in the Netherlands, EC, Federal Ministry for Economic Cooperation and Development in Germany, OECD, UNDP, UNEP and the World Bank.

World Meteorological Organisation (1999) Weather, climate and health. Message From Prof. G.O.P. Obasi, Secretary-General of WMO. World Meteorological Day 1999, WMO, Geneva. http://www.wmo.ch/web/Press/wmd99.html

Worrall, E. (2001) An economic evaluation of malaria early warning systems in Africa: a population dynamic modeling approach. PhD, Liverpool School of Tropical Medicine.

Yohe, G. and K. L. Ebi (2005) Approaching adaptation: parallels and contrasts between the climate and health communities. In Ebi, K., J. Smith and I. Burton (eds). Integration of Public Health with Adaptation to Climate Change: Lessons learned and New Directions. Taylor \& Francis Group, Lisse, The Netherlands. In press pp.18-45. 